\title{
Reference Re Supreme Court Act: Atlantic Canada and Regional Considerations in Supreme Court of Canada Appointments
}

\author{
Ian A McIsaac*
}

\section{Introduction}

In August 2016, Prime Minister Trudeau introduced a new Supreme Court of Canada ("SCC") appointment process to help find a replacement for Justice Thomas Cromwell. This process involved the creation of an independent and non-partisan panel to identify a short list of candidates for the Prime Minister to consider. The Prime Minister's instructions made clear that the panel could consider candidates from across the country, and not just Atlantic Canada, in replacing Justice Cromwell. ${ }^{1}$ This seemed to reflect the Prime Minister's goal to make an appointment that increased the Court's diversity, such as appointing Canada's first Indigenous Supreme Court judge. The Panel's report noted several other self-identified groups representing the diversity of the applicants, including Ethnic/Cultural, Visible Minority, Disabilities, and LGBTQ2. ${ }^{2}$ Yet, many Atlantic Canadians were alarmed that their "region" might not be represented at the Court, and one lawyers group filed a constitutional challenge in the Nova Scotia Supreme Court before the appointment was even made. ${ }^{3}$ Ultimately, the Prime Minister selected Justice Malcolm Rowe of the Newfoundland and Labrador Court of Appeal, a judge who has been viewed favourably by Atlantic Canadians. ${ }^{4}$ And, while the Atlantic lawyers group withdrew their application on Justice Rowe's appointment, their application nonetheless raises interesting ques- tions about the constitutional nature of regional appointments to the Supreme Court of Canada. ${ }^{5}$

In the Nadon Reference, the majority found that the Court's composition under section 41(d) of the Constitution Act, 1982 was codified by sections 4(1), 5, and 6 of the Supreme Court Act (SCA). These sections deal with the number of judges on the court, the minimum eligibility requirements, and the protection of Quebec's representation at the Court. Importantly, the Court seemed to suggest that this codification was exhaustive, meaning that the regional composition of the Court may not be protected. If this is the limit of constitutional protection in making judicial appointments, it does not provide adequate legal protection for the core principles that called for the Court's entrenchment in the first place. For example, the appointment powers under the Supreme Court Act could actually be used to undermine the federal and bijural nature of the Court, by appointing an entire panel of civil law judges or judges appointed from one region or province. A constitutional requirement for regional appointments may fill the gap in this protection for the Court as a federal and bijural institution. Of course, any such protection would have to comply with the plain language of the Supreme Court Act and the majority's decision in the Nadon Reference. Namely, the Court's composition clearly allows for deviations from the current regional composition by permitting more 
than three judges to be appointed from Quebec. This paper therefore advances the theory that each non-Quebec "region", as they are currently recognized, might need at least one appointee each in order to ensure the Court has functioning and legitimacy as a federal and bijural institution. This theory has the added benefit of providing the Governor-in-Council with flexibility in making appointments that meet other roles of the Court, such as adjudicating on Charter rights and aboriginal law.

\section{Supreme Court Act: Statute and Reference}

Appointments to the Supreme Court are governed by sections 4-6 of the Supreme Court Act. ${ }^{6}$ Section 4 allows the Governor in Council to appoint judges to the Court, and the Court is composed of a chief justice and eight puisne judges. Section 5 creates four groups of eligible appointees:

(1) current judges of a superior court of a province, including courts of appeal,

(2) former judges of such a court,

(3) current barristers or advocates of at least ten years' standing at the bar of a province, and

(4) former barristers or advocates of at least ten years' standing.?

Section 6 mandates that "at least three of the nine judges shall be appointed from among the judges of the Court of Appeal or of the Superior Court of the Province of Quebec or from among the advocates of that Province." The majority in Reference Re Supreme Court Act interpreted these sections to mean that the three Quebec appointees must be active at the bar or bench of the province and meet the seniority requirement set out in section $5 .{ }^{8}$

The majority also considered the purpose of these sections in the Nadon Reference. The purpose of section 5 is to "ensure that appointees to the Court have adequate legal experience" and to "articulate the minimum general eligibility requirements for the appointment of all Supreme
Court judges." Conversely, the purpose of Section 6 is to reflect the historical compromise that gained Quebec's acceptance for a national plan: "[the framers] saw the two seats (one third) for Quebec judges as a means of ensuring not only the functioning, but also the legitimacy of the Supreme Court as a federal and bijural institution." ${ }^{10}$ The majority also describes section 6 as having a "twofold purpose," which is:

(i) ensuring civil law expertise and the representation of Quebec's legal traditions and social values on the Court, and (ii) enhancing the confidence of Quebec in the Court. Requiring the appointment of current members of civil law institutions was intended to ensure not only that those judges were qualified to represent Quebec on the Court, but that they were perceived by Quebecers as being so qualified. ${ }^{11}$

Thus, the majority concluded that the purpose of section 6 is to:

[L]imit the Governor in Council's otherwise broad discretion to appoint judges, in order to ensure expertise in civil law and that Quebec's legal traditions and social values are reflected in the judges on the Supreme Court, and to enhance the confidence of the people of Quebec in the Court. ${ }^{12}$

Given the government's attempt to amend these appointment criteria to ensure Justice Nadon's appointment, the majority was also required to consider section $41(\mathrm{~d})$ of the Constitution Act 1982 (CA 1982) and the SCC's status under the Constitution of Canada. While the Supreme Court Act is not found in the list of instruments that comprise the Constitution of Canada, the majority determined that the Court's evolution into an essential institution necessitated its incorporation into the Constitution of Canada. Canada has always required a final appellate court and this role was performed at confederation by the Judicial Committee of the Privy Council ["JCPC"]. As noted by the majority: "Inherent in a federal system is the need for an impartial arbiter of jurisdictional disputes over the boundaries of federal and provincial powers... . That impartial arbiter is the judiciary, charged with "control[ling] the 
limits of the respective sovereignties." 13 This role gradually shifted to the SCC, and the process was completed when appeals to the JCPC were abolished in $1949 .{ }^{14}$ Besides acting as the final arbiter on federalism, the Court also played an essential role by unifying provincial jurisprudence. ${ }^{15}$ The Court's unifying role allowed the common law and the civil law to evolve together, while protecting the distinct character of each system. ${ }^{16}$ The SCC was therefore essential to the functioning of the law within each province, and "to the development of a unified and coherent Canadian legal system." ${ }^{17}$

While the Court had become "constitutionally essential" by at least 1949, the patriation of the Constitution in 1982 "confirmed" the Court's status within the constitutional "architecture."18 The Court's confirmation came, in part, because of Canada's shift from parliamentary to constitutional supremacy. ${ }^{19}$ As stated by the majority: "the existence of an impartial and authoritative judicial arbiter is a necessary corollary of the enactment of the supremacy clause. The judiciary became the 'guardian of the constitution"'. ${ }^{20}$ The confirmation of the Court's constitutional status in the CA 1982 meant that the essential features of the Court would be protected as part of the Constitution of Canada going forward. ${ }^{21}$

What were included as essential features? The Court left its criteria open, but did explain that the Court's composition was one "essential feature" that was singled out for special protection under section $41(\mathrm{~d})$ of the CA 1982.22 This meant that any changes to the composition would need the approval of Parliament and all the provinces. The majority found that the Court's "composition" was codified by sections 4(1), 5 , and 6 of the $S C A$. The codification also implied the Court's continued existence, as abolition would certainly alter this composition. ${ }^{23}$ The framers' intention in protecting the Court's composition was not only to make it difficult to alter the Court's composition, but also to affirm the special constitutional status of Quebec's judicial representation. ${ }^{24}$ As stated by the majority:

The fact that the composition of the Supreme Court of Canada was singled out for special protection in s. 41(d) is unsurprising, since the
Court's composition has been long recognized as crucial to its ability to function effectively and with sufficient institutional legitimacy as the final court of appeal for Canada. As explained above, the central bargain that led to the creation of the Supreme Court in the first place was the guarantee that a significant proportion of the judges would be drawn from institutions linked to Quebec civil law and culture. The objective of ensuring representation from Quebec's distinct juridical tradition remains no less compelling today, and implicates the competence, legitimacy, and integrity of the Court. ${ }^{25}$

The majority thus concluded:

Sections 4(1), 5 and 6 of the Supreme Court Act codify the composition of and eligibility requirements for appointment to the Supreme Court of Canada as they existed in 1982. Of particular relevance is s. 6 , which reflects the Court's bijural character and represents the key to the historic bargain that created the Court in the first place. As we discussed above, the guarantee that one third of the Court's judges would be chosen from Quebec ensured that civil law expertise and that Quebec's legal traditions would be represented on the Court and that the confidence of Quebec in the Court would be enhanced.

Both the general eligibility requirements for appointment and the specific eligibility requirements for appointment from Quebec are aspects of the composition of the Court. ${ }^{26}$

\section{Regional Representation}

It is unlikely that there is a legal rule mandating the current regional composition of the SCC. Simply put, the plain language of the $S C A$ does not require three Ontario, three Quebec, two Western, and one Atlantic appointed judges. ${ }^{27}$ All that is required by the text is for an appointee to be a barrister with ten years' standing at a provincial bar to be qualified to sit as a SCC judge, with the further requirement that at least three of the judges are to be appointed from among the judges or advocates of Quebec. What is more, the use of "at least" in section 6 of the SCA actually suggests the opposite to a legal rule for the current regional composition, as it allows for more 
than three judges to be appointed from Quebec's bench or bar.

Similarly, the majority's purposive interpretation of the SCA in the Nadon Reference does not require the current regional composition to be entrenched. As noted, the purpose of section 5 is to "ensure that appointees to the Court have adequate legal experience" and to "articulate the minimum general eligibility requirements for the appointment of all Supreme Court judges." ${ }^{28}$ Section 5 also gives the Governor-in-Council "broad discretion to appoint judges." 29 The purpose of section 6 is to "ensure not only civil law training and experience on the Court, but also to ensure that Quebec's distinct legal traditions and social values are represented on the Court, thereby enhancing the confidence of the people of Quebec in the Supreme Court as the final arbiter of their rights." ${ }^{30}$ In other words, section 6 "protects both the functioning and the legitimacy of the Supreme Court as a general court of appeal for Canada." ${ }^{31}$ The purpose of these sections is to ensure that appointees have the requisite legal skill and while properly accounting for Quebec and civil law; these sections are not about protecting the current regional composition of the Court.

The parliamentary debates surrounding key structural changes to the Court reflect this interpretation of sections 5 and 6 of the SCA. For example, when the Court was increased to seven judges in 1927, Justice Minister Lapointe emphasized the importance of merit in making appointments:

While geographical conditions should not be considered in the appointment of judges, because the best possible men should be appointed to the Supreme Court of Canada, there is one exception, namely that two judges will always be members of the bench or bar of Quebec, familiar with the civil law and procedure of that province. Apart from that there is no geographical condition mentioned in the act. I must say, however, that since the creation of the court such considerations have been taken into account in making appointments; there is one judge usually supposed to be a member of the bar or bench of one of the maritime provinces; two come from Quebec; two have usually been appointed from Ontario and one judge is usually appointed from the bench of British Columbia. The prairie provinces were not then developed as they are to-day, and up to the present there has not been a judge from either the bar or the bench of any of those provinces.. ${ }^{32}$

This focus is further illustrated by the 1949 debates on the various milestone changes to the Court, including increasing the numbers to nine judges and abolishing appeals to the JCPC. Here, Justice Minister Garson explained why regional representation should not be incorporated into the legislation:

I would not want anything I have said today to leave the impression that we regard it as a federal court representing localities. The intention is that we shall endeavour to get men of the very best legal ability in Canada to sit on this court, having regard to the fact that when it becomes a court of last resort for this country it will be exercising a type of jurisdiction considerably different from and much more onerous than that which it has exercised heretofore, when it was merely a court through which appeal went on their way to the court of last resort, the judicial committee of the privy council.

This being so, I believe there is a good deal of merit in the suggestion of the hon. member that it should be a federal court, and that the chief object should be to secure the very best talent available. Of course, if we can achieve that object and at the same time give representation to as many parts of Canada as possible, I am sure the hon. member would agree with me that the second objective is a desirable one so long as it can be attained without sacrificing the first.

So far as representation of Quebec is concerned, as I have already indicated, it is not in any sense a geographical representation, but rather one necessitated by the fact that unlike other countries, we have in one of our larger and more thickly populated provinces a civil code, which is a system of law quite distinct from the common law. In making the Supreme Court of Canada the court of last resort we have to make adequate provision to hear appeals from all parts of Canada, including Quebec. ${ }^{33}$ 
When asked about the qualification that "at least" three judges come from the bench or bar of Quebec, Minister Garson maintained that it was to ensure that the government could still appoint a high caliber appointment from Quebec, even if there were already three judges from that province on the bench:

If we said three, period, or three without adding the words "at least" that would indicate a geographical representation in a sense. In that way we could not, where the ability of a particular man was an issue, add to that number ....

I do not want the impression to be left from what I have said that it is a settled policy, that the government will invoke this power to appoint more than three judges from Quebec. It simply means that if some time later an extraordinary case ..., when there is a man the best qualified in Canada to fill a vacant appointment, he could be appointed if he should happen to live in Quebec. ${ }^{34}$

Therefore, the Court's interpretation of the SCA along with the historical parliamentary debates suggest that the current regional composition of the Court is not entrenched. This possibility is reinforced by the fact that, for the purposes of s. 41(d) of the CA 1982, the Court's composition seems to be exhaustively codified by sections $4(1), 5$, and 6 of the SCA. ${ }^{35}$ While any discussion of wider regional requirements in the Nadon Reference would have ultimately been obiter dictum, it is noteworthy that the majority made no effort to leave the Court's composition as an open list, unlike their discussion of the Court's essential features under section $42(1)(d) .{ }^{36}$

However, if the composition is exhaustively codified, then the broad appointment powers under the SCA could be used to undermine the very principles that the composition is meant to protect; namely, the functioning and legitimacy of the Court as a federal and bijural institution. In turn, a Court that is not functional or legitimate in these characteristics would have trouble fulfilling its role within the constitutional architecture. In short, there appears to be a fairly seri- ous gap in the constitutional protection for some of the essential features of the Court.

For example, regarding the Court's bijural nature, nothing under the SCA prevents the Governor in Council from appointing nine civil law judges, so long as the judges meet the minimum eligibility requirements when they are appointed. A court of this composition would clearly not be a bijural institution. Likewise, the SCA could also be used to undermine the Court's functioning or legitimacy as a federal institution. As noted by the majority, it is essential for the Court to act as an impartial arbiter in jurisdictional matters and also in exercising its unifying jurisdiction over provincial jurisprudence. Regarding the Court's role as an impartial arbiter, the apposite question may be whether a province or region would feel a reasonable apprehension of bias when having their jurisdictional issues determined by the Court. ${ }^{37}$ While it is difficult to imagine the Court ever actually being biased against a province or region, the Nadon Reference makes clear that the legitimacy of the Court is just as important as the Court actually carrying out a fair hearing. The Atlantic trial lawyers group certainly felt that an Atlantic appointed judge was important in upholding the region's confidence in the Court. ${ }^{38}$ The SCA appointment powers also raises further questions about what constitutional mechanism assures the Court's functioning as a federal institution. That is to say, if Atlantic Canada can be excluded at the Court, what protects the other regions? Indeed, as Justice Moldaver points out in dissent in the Nadon Reference, the SCA could even be used to undermine Quebec's representation, by appointing judges who only have a tenuous connection to that province. ${ }^{39}$

If section $41(\mathrm{~d})$ is indeed an exhaustive definition, it is arguable that the federal and bijural characteristics of the Court are protected by a constitutional convention or norm. The problem with this assertion, however, is that there are no legal remedies for breaching a convention or norm, and this particular norm seems like thin protection for the Court given its place within Canada's constitutional architecture. ${ }^{40}$ If this is the case, then it means that the protection of the Court as a federal and bijural institution rests 
largely in the hands of federal politicians. ${ }^{41}$ It is also arguable that the constitutional principle of judicial independence ensures that the Court has the ability and legitimacy to fulfil its constitutional role as described under the Nadon Reference. While judicial independence is important, there are still gaps in the legal protection for the Court's role, as judicial independence does not mandate bijural expertise and does not assure proper development of provincial civil law. Finally, judicial independence would not necessarily make the Court legitimate in the eyes of a region or province that was pointedly excluded from representation on the Court.

This gap in the Court's legal protection might be filled by a constitutional requirement for regional appointments, provided the requirement is sufficiently flexible to meet sections $4(1), 5$, and 6 of the SCA. Regional representation can support the functioning and legitimacy of the Court as a federal and bijural institution by ensuring that the common law is represented at the Court and by ensuring that judges are not appointed exclusively from one part of the country. Some form of regional representation is also crucial in facilitating the Court's role in unifying provincial jurisprudence, by ensuring diversity of knowledge and experience from amongst the common law provinces.

That being said, it is important to consider what aspects of regional representation might be constitutionally protected. If the goal is to protect the bijural nature of the Court, it is noteworthy that three judges are capable of providing the Court with functioning and legitimacy for civil law. While it is difficult to say how much common law representation is needed to ensure the functioning and legitimacy of the Court for common law, presumably it is no less than three judges as well. In terms of the Court as a federal institution, it is noteworthy that the majority in the Nadon Reference seems to approve the current composition as providing functioning and legitimacy, in spite of Ontario and Quebec having $2 / 3$ rds of the appointments and the remaining eight provinces having only $1 / 3$ of the appointments. ${ }^{42}$ This acceptance clearly permits a fairly significant concentration of appointments in two provinces. The federal nature of the Court must take into account the possibility that more than three judges may be appointed from Quebec's bench or bar. Therefore, the answer may be that while regional representation is an essential feature of the Court, it only requires that each non-Quebec region have at least one appointee. ${ }^{43}$ The upshot of this approach is that it mandates participation at the SCC for all regions and provides a base level of three common law judges, but remains flexible enough to appoint the best candidates for the position, including candidates that fill special needs of the Court.

Under this theory, the possibility of the composition being exhaustively defined is not problematic, because Section 42(1)(d) is the better fit to begin with. Regional representation is by nature a regional right, not a provincial right, and the " $7 / 50$ " amending formula only requires the input of regions, and not every single province. One way to consider this is that protection under section $42(1)(d)$ would prevent any change to Atlantic Canada's representation without some support from that region. Conversely, it would be improper to protect regional representation under 41(d), because one Atlantic province could derail an attempt to amend this requirement, in spite of not being entitled to an appointee. Finally, the theory that each region is entitled to at least one appointee on the Court reflects the balancing required between the various relevant constitutional principles. For example, this theory supports the federalism principle by ensuring that the various regions of the country are represented at all times at the SCC, but it also gives the Governor-in-Council the flexibility it needs in order to make appointments that ensure that the principle of minority protection is also upheld. Notably the principle of minority protection includes the protection of aboriginal rights and peoples. ${ }^{44}$ Giving proper weight to both individual and regional diversity properly reflects the principles of federalism and protection of minorities in the constitution, and would support the Court's functioning and legitimacy when dealing with individual Charter rights and aboriginal law.

While it is easy enough to say that each "region" is entitled to a Supreme Court appoin- 
tee, there are numerous problems with entrenching such a rule. First, it is somewhat presumptuous to assume that a "region" like Atlantic Canada is a homogenous unit. There are many differences between Atlantic provinces and the people who inhabit them. The same can be said for the other SCC 'regions' in Canada. It is also difficult to determine which individuals are actually qualified to represent a region. Quebec's situation is clear: at least three judges must be appointed from the province, and appointments must be made from among the current judges or advocates of that province with ten years' standing. Establishing an Atlantic province is clear enough, but determining personal eligibility is less so. The best that can be said is that the SCA requires a person to have ten years' standing at $a$ provincial bar to be qualified for appointment, and referring to a singular province might provide sufficient direction for making a "regional appointment." For example, only a person with ten years' experience at an Atlantic bar would qualify a person to be appointed from that region. But, whatever certainty such an interpretation would give, it would be fairly meaningless without a currency requirement similar to that of Quebec. ${ }^{45}$

\section{Conclusion}

Regional representation is probably required to fill the gaps left by the codification of the Court's composition. The codification allows too much latitude in making SCC appointments and could be used to undermine the bijural and federal aspects of that institution. For example, the exclusion of Atlantic Canada from the Court could easily undermine the legitimacy of the Court in that region. If the constitution does allow for a single region to be excluded from the Court, where does it stop? Put another way, what legal mechanism will protect the functioning and legitimacy of the Court once deviations from the regional composition start? That being said, the entrenchment of regional representation cannot be used to upset the powers set out in codification and must be flexible enough to match demographic changes between the various 'regions'. What is more, regional representation cannot be used to preclude other goals, such as having indigenous representation or increasing other types of diversity. Indeed, while it is not directly addressed in the Nadon Reference, the Court's role in relation to individual and aboriginal rights since at least 1982 is surely just as important as its role in deciding jurisdictional issues. Restricting the regional requirement to one judicial appointee per region allows for flexibility in meeting these other goals while protecting the other core responsibilities of the Court. Thus, it is important to remember that while regional representation supports the Court's functioning and legitimacy as a federal and bijural nature, these are not the only relevant aspects of the Court and any constitutional rules regarding appointments should reflect this reality.

\section{Endnotes}

* Ian McIsaac, BA, JD, is a sole practitioner working in Truro, Nova Scotia and is the Nova Scotia chair for the Canadian Barristers Association Constitutional and Human Rights Law section. The author thanks the editorial staff at the Constitutional Forum for their assistance in preparing this article, along with Myrna Gillis, QC, Dennis James, QC, Kelly McMillan, and Danielle Dorn Kouwenberg for reviewing earlier drafts. The author very humbly dedicates this article to the late Professor Dianne Pothier, who undoubtedly would have provided a much more illuminating view on the topic.

1 "Independent Advisory Board for Supreme Court of Canada Judicial Appointments from Prime Minister Justin Trudeau" (4 August 2016), Office of the Prime Minister, online: <http://www.pm.gc. ca/eng/news/2016/08/04/mandate-letter-chairindependent-advisory-board-supreme-courtcanada-judicial $>$. Also, this paper uses Atlantic Canada to describe Nova Scotia, New Brunswick, Prince Edward Island, and Newfoundland and Labrador and occasionally uses this term out of ease to describe the "Maritime provinces" that comprised the East coast provinces up to 1949.

2 Report of the Independent Advisory Board for Supreme Court of Canada Judicial Appointments (August - September 2016) at 8; Justin Trudeau, "Why Canada has a new way to choose Supreme Court judges" Globe and Mail (2 August 2016), 
online: <http://www.theglobeandmail.com/ opinion/why-canada-has-a-new-way-to-choosesupreme-court-judges/article31220275/>; Ian MacLeod \& Jason Fekete, "Pressure to name first indigenous Supreme Court judge could see Trudeau shaking up rules" National Post (16 September 2016), online: <http://news. nationalpost.com/news/canada/canadian-politics/ pressure-to-name-first-indigenous-supremecourt-judge-could-see-trudeau-shaking-uprules $>$.

3 Canadian Press, "Atlantic Canada lawyers challenge Trudeau on changes to Supreme Court appointment process" CBC News (19 September 2016), online: <http://www.cbc.ca/news/politics/ atlantic-lawyers-supreme-court-1.3769108> .

4 John Paul Tasker, "Trudeau nominates Newfoundlander Malcolm Rowe to Supreme Court" CBC News (October 17, 2017), online: $<$ http://www.cbc.ca/news/politics/trudeausupreme-court-newfoundlander-1.3808384>.

5 Reference re Supreme Court Act, ss. 5 and 6, 2014 SCC 21 at para 28, [2014] 1 SCR 433 [Nadon Reference].

6 Supreme Court Act, RSC 1985, c S-26 [SCA].

7 Nadon Reference, supra note 6 at para 28.

$8 \quad \mathrm{Ibid}$ at para 37.

9 Ibid at paras 33 and 59.

10 Ibid at para 55.

$11 \mathrm{Ibid}$ at para 56.

12 Ibid at para 59.

$13 \mathrm{Ibid}$ at paras 82-83.

$14 \mathrm{Ibid}$ at paras 80,82 , including per saltum provincial appeals.

15 Ibid at para 85. For the jurisdiction of the of the Supreme Court of the United States see Peter Hogg, Constitutional Law of Canada 5th ed, vol 1 (Toronto: Thomson Carswell, 2007) (loose-leaf revision 2010-1) 8:11.

16 Nadon Reference, supra note 6 at para 85.

17 Ibid at para 85.

18 Ibid at paras 87-88.

19 Ibid at para 89.

20 Ibid at para 89.

21 Ibid at para 76.

22 The essential features of the Court include: "the Court's jurisdiction as the final general court of appeal for Canada, including in matters of constitutional interpretation, and its independence." Ibid at para 94.

23 Ibid at para 91.

24 Ibid at para 92

25 Ibid at para 93.

26 Ibid at paras at 104-105.
27 This is reinforced by the historical record. Deviations in regional representation were typical before 1949, see Peter Russell, The Supreme Court of Canada as a Bilingual and Bicultural Institute, (Ottawa: Information Canada, 1969) at 64. After 1949, from 1979 to 1982 there were three judges appointed from Western provinces (Justices Dickson, Martland and McIntyre): see generally, Supreme Court of Canada, The Supreme Court of Canada and its Justices 1875-2000: A Commemorative Book, (Toronto: Dundurn Group and the Supreme Court of Canada in Cooperation with Public Works and Government Services Canada, 2000).

28 Nadon Reference, supra note 6 at paras 33, 59.

29 Ibid at para 59.

30 Ibid at para 49.

31 Ibid at para 49.

32 House of Commons Debates, 16th Parl, 1st Sess, Vol 1 (10 March 1927) at 1079 (Hon Ernest Lapointe).

33 House of Commons Debates, 21st Parl, 1st Sess, Vol 1 (11 October 1949) at 663 (Hon Stuart Garson).

34 House of Commons Debates, 21st Parl, 1st Sess, Vol 1 (11 October 1949) at 664-665 (Hon Stuart Garson).

35 Nadon Reference, supra note 6 at paras 91, 104, 105.

$36 \mathrm{Ibid}$ at para 94.

37 As noted, the Court says that the Court needs to act as an "impartial arbiter" for jurisdictional disputes. The test for bias is set out by Grandpre J in Committee for Justice and Liberty $v$ National Energy Board, [1978] 1 SCR 369 at 394, 68 DLR (3d) 716: "[T] he apprehension of bias must be a reasonable one, held by reasonable and right minded persons, applying themselves to the question and obtaining thereon the required information. In the words of the Court of Appeal, that test is "what would an informed person, viewing the matter realistically and practically - and having thought the matter through - conclude..." In administrative law, the test for institutional impartiality requires a reasonable apprehension of bias in "a substantial number of cases": C.U.P.E. $v$ Ontario (Minister of Labour), 2003 SCC 29 at para 195, [2003] 1 SCR 539 [C.U.P.E.]. It is unclear if these tests are what were contemplated by the majority in the Nadon Reference when referring to an "impartial arbiter."

38 Atlantic Provinces Trial Lawyers Association $v$ The Right Honourable Prime Minister of Canada and the Governor General of Canada (19 September 2016), Halifax, NSSC SH-455561 (notice of application) at para 19.

39 Nadon Reference, supra note 6 at para 150. 
40 For constitutional conventions, see: Reference re Questions Concerning Amendment of the Constitution, [1981] 1 SCR 753, 125 DLR (3d) 1. For a more specific discussion on the SCC, Atlantic Canada, and constitutional architecture, see Jennifer Taylor, "The Atlantic Seat: Part of Canada's Constitutional Architecture?" CBA National Magazine (5 August 2016), online: <http://www.nationalmagazine.ca/ Blog/August-2016/The-Atlantic-seat-Part-ofCanada-s-constitutional.aspx $>$. The Atlantic Provinces Trial Lawyers Association advanced the following argument regarding conventions and the constitution, supra note 42 at para 20 : "Departure from the constitutional convention of regional representation on the Supreme Court of Canada changes the architecture of the Court, and disregards the fundamental role of federalism underlying both the interpretation of the Constitution, and the formation of the Court itself as an institution within the federal scheme. It is an amendment to the Constitution of Canada in relation to the composition of the Supreme Court of Canada, and thereby invokes the unanimous consent amending procedure, s. $41(\mathrm{~d})$ of the Constitution Act, 1982."

41 Of course, the principles of administrative law circumscribe statutory decision-makers in their actions. See for example, the review of labour arbitrator appointments by the SCC in C.U.P.E., supra note 41. As Justice Binnie states at para 172: "a statutory decision maker is required to take into consideration relevant criteria, as well as to exclude from consideration irrelevant criteria. ... [T] he failure of an administrative decision-maker to take into account a highly relevant consideration is just as erroneous as the improper importation of an extraneous consideration... ." The CUPE decision also raises interesting administrative law questions about the Prime Minister's instructions that the panel only consider "functionally bilingual" candidates in light of the majority's treatment of substantive changes to the eligibility requirements in the Nadon Reference at para 106. Namely, did the process fail to place the correct weight on the correct criteria, and thereby exclude candidates from consideration? But see Sébastien Grammond regarding bilingualism at the SCC: "Can Parliament enact a requirement that Supreme Court judges be bilingual?" Administrative Law Matters (13 May 2016), online: <http://www. administrativelawmatters.com/blog/2016/05/13/ guest-post-sebastien-grammond-can-parliamentenact-a-requirement-that-supreme-court-judgesbe-bilingual/ $>$.

42 See generally Russell, supra note 27.

43 This flexible theory for regional representation seems to comply with the situation in 1979 to 1982 , where three 'Western' appointed judges served on the SCC at the same time, supra note 29.

44 Reference re Secession of Quebec, [1998] 2 SCR 217 at para 82, 161 DLR (4th) 385.

45 Interestingly, there is precedent for a non-Atlantic resident being appointed for that region. In 1924, Sir Louis Henry Davies from PEI was replaced on the bench by Edmund Newcombe, a Nova Scotian who had moved to Ottawa in 1893 and served as the Deputy Minister of the Department of Justice. Russell, supra note 29 at 64 counts Justice Newcombe as an Ontario appointment, but perhaps Prime Minister Mackenzie King viewed Justice Newcombe as sufficiently "Atlantic" to serve on the bench from that region. There does not seem to be any doubt by Russell that Newcombe's successor, Justice Oswald Crocket, was an Atlantic Canadian. See also, Supreme Court of Canada, The Supreme Court of Canada and its Justices 18752000: A Commemorative Book, (Toronto: Dundurn Group and the Supreme Court of Canada in Cooperation with Public Works and Government Services Canada, 2000). 
